\title{
Advances in agronomic management of phytoremediation: methods and results from a 10-year study of metal-polluted soils
}

\author{
Teofilo Vamerali, ${ }^{1}$ Luca Marchiol,, ${ }^{2}$ Marianna Bandiera, ${ }^{3}$ Guido Fellet, ${ }^{2}$ \\ Nicholas M. Dickinson, ${ }^{4}$ Paola Lucchini, ${ }^{3}$ Giuliano Mosca, ${ }^{3}$ Giuseppe Zerbi ${ }^{2}$ \\ ${ }^{1}$ Department of Food Sciences, University of Parma, Italy; ${ }^{2}$ Department of Agriculture and \\ Environmental Sciences, University of Udine, Italy; ${ }^{3}$ Department of Agronomy, Food, Natural \\ Resources, Animals and the Environment, University of Padova, Legnaro (PD), Italy; ${ }^{4}$ Department \\ of Ecology, Lincoln University, Canterbury, New Zealand
}

\begin{abstract}
Among green technologies addressed to metal pollution, phytoextraction has received increasing attention in recent years as an alternative to physical and chemical methods of decontamination. Since 1998 , as part of an Italian multidisciplinary research team on phytoremediation, we have been carrying out several agronomic investigations with field crops in agricultural soil and pyrite waste, both markedly contaminated by heavy metals. Phytoextraction was rarely an efficient process, requiring a long time even to remove merely the bioavailable metal fraction, but the great metal stock in roots suggests exploring the effectiveness of long-term in planta stabilisation. Poor above-ground productivity was the main factor constraining metal removals, especially in wastes. Without assisting the process, only zinc $(\mathrm{Zn})$, manganese $(\mathrm{Mn})$ and copper $(\mathrm{Cu})$ were harvested by the canopy in substantial amounts, with an estimated maximum of $\sim 8 \mathrm{~kg}$ of metals from an hectare base with rapeseed in the agricultural soil and only $0.33 \mathrm{~kg}$ with fodder radish in pyrite waste. Root growth was a key trait
\end{abstract}

Correspondence: Prof. Teofilo Vamerali, Department of Food Sciences, University of Parma, Parco Area delle Scienze 11/A, 43124 Parma, Italy. Tel. +39.0521 .905486 - Fax: +39.0521 .905402 .

E-mail: teofilo.vamerali@unipr.it

Key words: agronomic practices, crop species, heavy metals, phytoremediation, roots, soil pollution.

Acknowledgements: this research received financial support from the Italian Ministry of University and Scientific Research (MIUR) (PRIN, Research Programs of Substantial National Interest) and from the University of Padova. The authors wish to thank Gabriel Walton for revision of the English text.

Received for publication: 5 April 2012.

Accepted for publication: 8 September 2012.

(C) Copyright T. Vamerali et al., 2012

Licensee PAGEPress, Italy

Italian Journal of Agronomy 2012; 7:e42

doi:10.4081/ija.2012.e42

This article is distributed under the terms of the Creative Common Attribution Noncommercial License (by-nc 3.0) which permits any noncommercial use, distribution, and reproduction in any medium, provided the original author(s) and source are credited. in species and genotype selection, in view of the close relationship between root length and metal uptake. The auxins, humic acids and chelators tested on the model plant fodder radish generally increased metal concentrations in plant tissues, but reduced growth and removals. It is currently concluded that phytoremediation efficiency with crop species may be improved through increased productivity by suitable soil management, involving mineral and organic fertilisation, contaminant dilution, soil capping, and metal immobilisation with inorganics and biochar.

\section{Introduction}

Soil contamination by heavy metals as a consequence of human activities is one of the main concerns in environmental protection, raising the risk of metal movements towards other compartments, such as water, air and biota. According to the European Environment Agency (2011), the number of contaminated sites in the EU is estimated at approximately 250,000 , but is predicted to increase $50 \%$ by 2025 . Industrial and commercial activities, as well as treatment and disposal of wastes, account for the main sources of contamination, and the most frequent contaminants are represented by heavy metals ( $\sim 37 \%$ of cases).

In the last 15 years, the Italian Ministry for the Environment and Territory and Sea Protection has identified 58 large sites of national interest for remediation, corresponding to approximately $3 \%$ of the Italian territory, but several cases are still under observation. Contaminated sites are still managed almost exclusively by invasive and highly expensive physical and chemical methods of decontamination. In this framework, there is interest in identifying low-cost, mild, green technologies, an opportunity suggested by the great potential of phytoremediation against organic and inorganic contaminants (Lasat, 2002; Ernst, 2005). For trace elements, efficient cultivation of higher plants and harvesting of their above-ground biomass, known as phytoextraction, has been highlighted since the 1990s (Raskin et al., 1994) with the discovery of hyperaccumulators. These species concentrate only a few metals at high levels without showing evident symptoms of phytotoxicity, but provide very small above-ground biomass. Currently, much attention focuses on biomass species, including field crops, which need proper definition of agronomic management for their suitable application in pluri-contaminated sites. Several species belonging to Brassicaceae, Poaceae, Fabaceae and Asteraceae have been tested in phytoremediation over the last 10 years. In particular, Brassica juncea L. Czern. (Indian mustard), Helianthus annuus L. (sunflower), B. napus L. var. oleifera D.C. (rapeseed) and Zea mays L. (maize) have been cited at increasing rates over time (Vamerali et al., 2010). 
As from 1998, a multidisciplinary research team involving the Universities of Udine, Padova, Milano, Pisa, Firenze and Parma has been studying the phytoremediation potential of crop species at laboratory, greenhouse and field levels. Several PRINs (Research Programs of Substantial National Interest) have been financially supported by the Italian Ministry of Education, University and Research, focusing on the effects of metals on germination, and shoot and root growth, methods for assisting phytoextraction, and possible related environmental risks. We present here a summary of the main results of 10 years of study, with particular reference to the agronomic management of field crops in two real-life contaminated sites in Italy.

\section{Materials and Methods}

\section{Description of polluted field sites}

Two metal-contaminated sites were identified in north Italy as suitable for carrying out on-site and pot experiments. Preliminary trials were set up at a farm in Carpiano (Milano, Italy, 45 20'31" N, 9 ${ }^{\circ} 17^{\prime} 11^{\prime \prime}$ E, $91 \mathrm{~m}$ asl), where the soil had been cultivated for several years as a water meadow, and contamination was due to irrigation water withdrawn from the nearby Lambro river. The soil was a Fluventic Dystrochrepts, rich in organic matter $\left(69 \mathrm{~g} \mathrm{~kg}^{-1} \mathrm{DW}\right)$, with $\mathrm{pH} 6.3$ and a loamy-sand texture (37\% sand, 53\% silt) (Zaccheo et al., 2006). Metal contamination largely exceeded the Italian Guideline Values (IGV) for Green public, private and residential areas (Italian Legislative Decree 152/2006) (Table 1).

A second site was identified at Torviscosa (Udine - Italy, $45^{\circ} 49^{\prime} 23^{\prime \prime}$ $\mathrm{N}, 13^{\circ} 16^{\prime} 40^{\prime \prime} \mathrm{E}, 3 \mathrm{~m}$ asl) close to a chemical factory and within the polluted site Lagoon of Grado and Marano and adjacent rivers, which is included in the Italian priority list for remediation. Pollution was due to As- and metal-contaminated pyrite cinders, discharged between the 1940 s and the late 1970s as by-products of pyrite ore roasting for sulphur extraction. The cinders extended for a depth of $0.7 \mathrm{~m}$ over a deep clay horizon, and were capped with $0.15 \mathrm{~m}$ of unpolluted gravelly soil. Largely devoid of organic matter, with high bulk density $\left(1.65 \mathrm{~g} \mathrm{~cm}^{-3}\right)$, poor in nutrients, $\mathrm{pH} 7.3$, and relatively low electrical conductivity $(0.3$ $\mathrm{S} \mathrm{m}^{-1}$ ), the cinders had been colonised by a sparse vegetation cover (Coletto et al., 2006). Metal concentrations in cinders greatly exceeded the IGV, 45 times for arsenic (As), $23 \times$ for copper (Cu), 16× for zinc (Zn), $5 \times$ for cobalt $(\mathrm{Co})$ and lead (Pb), and $3 \times$ for cadmium (Cd). Arsenic and $\mathrm{Cu}$ levels were particularly high, exceeding the less restrictive IGV for Industrial sites (i.e. 50 and $600 \mathrm{mg} \mathrm{kg}^{-1} \mathrm{DW}$, respectively) (Table 2).

On site, the response of some crop species was compared at plant maturity at Carpiano during 2003, and plant behaviour was observed under two soil management options (ploughing $v s$ subsoiling) and fertilisation schemes (mineral $v s$ organic) at Torviscosa across years 2005 and 2006. In the field, we adopted a randomised block and a split-plot experimental design, at the two sites respectively, with 3 replicates (10$\mathrm{m}^{2}$ plots).

\section{Germination and initial growth under cadmium and chromium}

The first experiments evaluated metal toxicity on germination and initial growth over the 1998-2000 period. Germination, biomass and metal uptake of several Brassicaceae species and genotypes were revealed under increasing $\mathrm{Cd}$ and chromium (Cr) (Bona et al., 2002a, 2002b). We present here some results regarding Indian mustard (cultivars WNFP, Varuna and Barton), which was cultivated hydroponically for 4 weeks. Seeds were germinated in sand watered with Hoagland solution, added with $\mathrm{Cd}$ or $\mathrm{Cr}$ as $\mathrm{Cd}\left(\mathrm{NO}_{3}\right)_{2}$ and $\mathrm{K}_{2} \mathrm{Cr}_{2} \mathrm{O}_{7}$, at concentra- tions of $0.5,1$ and $1.5 \mu \mathrm{M}$. One week after sowing, seedlings were transferred to 2.5 -L beakers containing aerated nutrient solution, polluted or not with the same $\mathrm{Cd}$ and $\mathrm{Cr}$ concentrations. At the end of the experiment, leaf area was measured with a leaf area meter (LiCor3000 , LiCor). The fresh and dry weight of leaves, stems and roots $(n=5)$ were measured and $\mathrm{Cd}$ and $\mathrm{Cr}$ concentrations determined by ICP-AES (Spectro CirosCCD) after microwave acid-digestion (USEPA, 1994). The translocation factor, i.e. shoot-to-root metal concentration ratio, was calculated as an index of phytoextraction potential.

\section{Pot trials with agricultural soil and pyrite waste}

Various pot experiments were carried out with the agricultural soil of Carpiano and the pyrite cinders; the latter were mixed with sand (1:1 w/w) or with the capping soil of the site. Across years 2001 and 2002, some Brassicaceae species were cultivated in rhizoboxes with the Carpiano soil, focusing on root growth and metal accumulation at an early stage. Further investigations were carried out on mature plants of fodder radish during 2003 in order to reveal intraspecific variability for metal tolerance.

On pyrite cinders, the effects of pollutant dilution by mixing with top-soil ( $50 \%$ and $66 \% \mathrm{v} / \mathrm{v}$ ) were examined in 2004 on soybean (Glycine $\max ($ L.) Merr.), sorghum (Sorghum bicolor (L.) Moench.), sunflower and maize.

Other pot trials on pyrite cinders regarded the application of humic acids, indolebutyric acid (IBA) and ethylene diamine disuccinic acid (EDDS), in years 2006, 2007 and 2008, respectively, in order to improve plant growth and metal uptake. These experiments involved fodder radish (Raphanus sativus L. var. oleiformis Pers.), which showed generally good productivity under contamination and, for the EDDS study only, also Ethiopian mustard (Brassica carinata A. Braun). Plants were grown for $\sim 3$ months in $57-\mathrm{mm}$ diameter, 520 -mm high pots $(1.3 \mathrm{~L} \mathrm{vol}$ ume) filled with the pyrite cinder-sand mixture and regularly watered with 50\%-diluted Hoagland solution. Leachates were collected throughout the experiments in order to detect metal losses. Treatments were compared with untreated controls (5 replicates).

Humic acids were obtained from a commercial source and were applied as follows: foliar spraying $\left(0.1 \mathrm{~g} \mathrm{~L}^{-1}\right.$ solution, $4 \mathrm{~mL}$ per plant once a week for 3 weeks), mixed with the substrate before sowing (two dosages: 0.1 and $\left.1 \mathrm{~g} \mathrm{~kg}^{-1}\right)$, in combination or not with foliar treatment, and the low rate $\left(0.1 \mathrm{~g} \mathrm{~kg}^{-1}\right)$ applied at sowing through irrigation (6 treatments).

IBA was applied 5 times during the growing period at 10-day intervals, either by foliar spraying ( $10 \mathrm{mg} \mathrm{L}^{-1}$ solution, $4 \mathrm{~mL}$ per plant), or substrate irrigation at doses of 0.1 and $1 \mathrm{mg} \mathrm{kg}^{-1}$ substrate, in association or not with foliar spraying (5 treatments).

As regards the chelator EDDS, we tested the rapidly degradable [S,S]-stereoisomer at various doses and application times: 2.5 and 5 mmol kg-1 substrate applied through irrigation one week before harvest, and $1 \mathrm{mmol} \mathrm{kg}^{-1}$ soil repeated five times at 5 - or 10-day intervals, respectively starting 48 or 28 days after sowing (DAS) (4 treatments).

\section{Inorganic amendments}

During 2008, we tested metal mobility in a canal sediment after the addition of cement $(1 \%, 20 \%$, and $50 \% \mathrm{w} / \mathrm{w})$, lime ( $1 \% \mathrm{w} / \mathrm{w})$, and lime + iron sulphate $(0.5 \% \mathrm{w} / \mathrm{w}$ each) (5 treatments), in comparison with untreated controls. The sediment, collected at the Woolston New Cut Canal (Warrington, UK) was silty loam, with negligible calcium carbonate content, high organic matter and a low oxidised pH. In order to mimick canal conditions, where sediment is cyclically exposed to flooding and drying, four cycles of wet-and-dry extraction were performed on samples of about $1 \mathrm{~g}$, added with $15 \mathrm{~mL}$ of deionised water ( $\mathrm{n}=3$ ). After 24-hour shaking (200 rpm) and centrifugation (3,000 rpm), the supernatant was collected and analysed by ICP-OES for determination of $\mathrm{Cd}, \mathrm{Cu}, \mathrm{Pb}$, and 
$\mathrm{Zn}$ contents. Pellets were oven-dried at $45^{\circ} \mathrm{C}$ for $24 \mathrm{~h}$ and then resuspended in water for the following cycle. A further experiment with biochar amendment of mine waste (Predil mines, Julian Alps, NE Italy) was also carried out in 2009 , in order to evaluate possible influences on metal mobility and bioavailability. Mine tailings were severely contaminated by $\mathrm{Cd}\left(26 \mathrm{mg} \mathrm{kg}^{-1}\right)$, Pb (2873 $\left.\mathrm{mg} \mathrm{kg}^{-1}\right)$, Tl (130 mg kg-1) and $\mathrm{Zn}$ $\left(11,519 \mathrm{mg} \mathrm{kg}^{-1}\right)$. Biochar was derived from pyrolysis of orchard pruning residues and was tested at doses of $1 \%, 5 \%$ and $10 \% \mathrm{w} / \mathrm{w}$ (3 treatments).

\section{Results and Discussion}

\section{Germination and seedling growth under cadmium and chromium}

Indian mustard germinated regularly even at the highest metal concentration of $1.5 \mu \mathrm{M}$, but biomass at early stages varied significantly, according to the level of $\mathrm{Cd}$ and $\mathrm{Cr}$ (Figure 1). Chromium was more phytotoxic than $\mathrm{Cd}$, causing a greater plant biomass reduction, especially in WNFP and Varuna (-37\% over controls, at $0.5 \mu \mathrm{M})$, whereas Barton showed a certain tolerance.

Metal concentrations in the plant structures increased with contamination level, with significant differences among cultivars. In leaves, maximum Cd was $80 \mathrm{mg} \mathrm{kg}^{-1}$ and maximum $\mathrm{Cr} 6 \mathrm{mg} \mathrm{kg}^{-1}$, both in $\mathrm{cv}$. Varuna. Brassica juncea was confirmed as a species tolerant to these metals, probably due to poor translocation values, especially for $\mathrm{Cr}$. Although $\mathrm{Cd}$ reached a translocation factor of 15 maximum, that of $\mathrm{Cr}$ was often below 1, meaning that a large metal fraction remained in roots (Marchiol et al., 2006).

These preliminary results indicate that Brassica juncea is not very sensitive to hazardous metals, and the high intraspecific variability suggests exploring a wider number of genotypes. However, further investigations should also consider adult plants in real polluted soil.
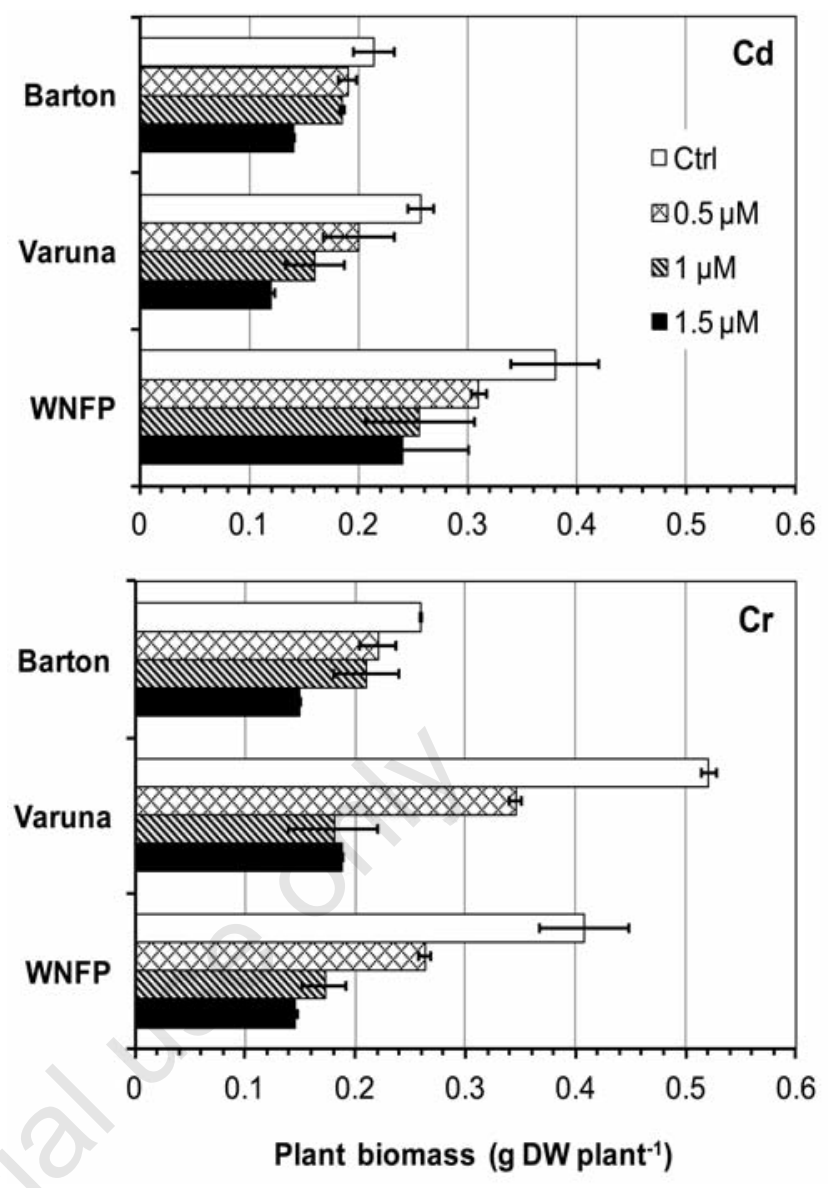

Figure 1. Hydroponic experiment: biomass $( \pm S E, n=5)$ of 4-weekold seedlings in 3 cultivars of Brassica juncea under increasing cadmium $(\mathrm{Cd})$ and chromium $(\mathrm{Cr})$ concentrations in solution, compared with uncontaminated controls (Ctrl).

Table 1. Site of Carpiano: soil metal concentrations in two experiments and Italian Guideline Values for Green public, private and residential areas (Italian Legislative Decree 152/2006).

$\begin{array}{lcccccccc} & \begin{array}{c}\mathrm{Cd} \\ \left(\mathrm{mg} \mathrm{kg}^{-1}\right)\end{array} & \begin{array}{c}\mathrm{Co} \\ \left(\mathrm{mg} \mathrm{kg}^{-1}\right)\end{array} & \begin{array}{c}\mathrm{Cr} \\ \left(\mathrm{mg} \mathrm{kg}^{-1}\right)\end{array} & \begin{array}{c}\mathrm{Cu} \\ \left(\mathrm{mg} \mathrm{kg}^{-1}\right)\end{array} & \begin{array}{c}\mathrm{Mn} \\ \left(\mathrm{mg} \mathrm{kg}^{-1}\right)\end{array} & \begin{array}{c}\mathrm{Ni} \\ \left(\mathrm{mg} \mathrm{kg}^{-1}\right)\end{array} & \begin{array}{c}\mathrm{Pb} \\ \left(\mathrm{mg} \mathrm{kg}^{-1}\right)\end{array} & \begin{array}{c}\mathrm{Zn} \\ \left(\mathrm{mg} \mathrm{kg}^{-1}\right)\end{array} \\ \text { IGV } & 2 & 20 & 150 & 120 & - & 120 & 100 & 150 \\ \begin{array}{l}\text { Pot experiment } \\ \text { (years 2001-2002) }\end{array} & 89.9 \pm 5.7 & \text { nd } & 452 \pm 34 & 953 \pm 68 & \text { nd } & \text { nd } & 2279 \pm 186 & 15,159 \pm 1466 \\ \text { Field experiment } & 7.50 \pm 0.47 & 9.38 \pm 0.23 & 142 \pm 11 & 135 \pm 10 & 1073 \pm 17 & 50.7 \pm 1.8 & 231 \pm 19 & 2113 \pm 204\end{array}$

(year 2003)

Cd, cadmium; Co, cobalt; Cr, chromium; Cu, copper; Mn, manganese; Ni, nickel; Pb, lead; Zn, zinc; IGV, Italian Guideline Values; nd, not determined. Values are indicated as \pm SE, $\mathrm{n}=3$.

Table 2. Site of Torviscosa: total and DTPA-extractable metal concentrations in pyrite waste and top 0.15-m mixed soil-waste (after tillage), in comparison with reference uncontaminated silty-loam soil at Legnaro (Padova, Italy).

\begin{tabular}{|c|c|c|c|c|c|c|c|c|}
\hline & \multirow[t]{2}{*}{ IGV } & \multirow{2}{*}{$\begin{array}{l}\text { Pyrite } \\
\text { waste } \\
\text { Total }\end{array}$} & \multicolumn{2}{|c|}{$\begin{array}{l}\text { Mixed soil-waste } \\
\text { Ploughing }\end{array}$} & \multicolumn{2}{|c|}{$\begin{array}{l}\text { Mixed soil-waste } \\
\text { Ripping }\end{array}$} & \multicolumn{2}{|c|}{ Reference soil } \\
\hline & & & Total & DTPA-extractable & Total & DTPA-extractable & Total & DTPA-extractable \\
\hline As $\left(\mathrm{mg} \mathrm{kg}^{-1}\right)$ & 20 & $892 \pm 15$ & $423 \pm 46$ & nd & $292 \pm 37$ & nd & $15.5 \pm 0.9$ & nd \\
\hline $\mathrm{Cd}\left(\mathrm{mg} \mathrm{kg}^{-1}\right)$ & 2 & $5.09 \pm 0.21$ & $2.67 \pm 0.42$ & $0.31 \pm 0.08$ & $1.67 \pm 0.20$ & $0.16 \pm 0.02$ & $0.38 \pm 0.03$ & $0.09 \pm 0.01$ \\
\hline $\mathrm{Co}\left(\mathrm{mg} \mathrm{kg}^{-1}\right)$ & 20 & $102 \pm 8$ & $41.6 \pm 5.0$ & nd & $29.5 \pm 3.5$ & nd & $7.95 \pm 0.34$ & nd \\
\hline $\mathrm{Cu}\left(\mathrm{mg} \mathrm{kg}^{-1}\right)$ & 120 & $2726 \pm 199$ & $1719 \pm 228$ & $291 \pm 39$ & $1103 \pm 155$ & $190 \pm 25$ & $31.1 \pm 2.1$ & $4.51 \pm 0.28$ \\
\hline $\mathrm{Pb}\left(\mathrm{mg} \mathrm{kg}^{-1}\right)$ & 100 & $495 \pm 30$ & $118 \pm 9$ & $15.7 \pm 1.9$ & $89.8 \pm 14.9$ & $10.3 \pm 2.0$ & $17.9 \pm 1.3$ & $2.96 \pm 0.25$ \\
\hline $\mathrm{Zn}\left(\mathrm{mg} \mathrm{kg}^{-1}\right)$ & 150 & $2410 \pm 241$ & $860 \pm 66$ & $30.2 \pm 5.3$ & $674 \pm 46$ & $24.1 \pm 2.0$ & $79.5 \pm 4.1$ & $1.21 \pm 0.13$ \\
\hline
\end{tabular}

As, arsenic; Cd, cadmium; Co, cobalt; Cr, chromium; Cu, copper; Pb, lead; Zn, zinc; IGV, Italian Guideline Values; nd, not determined. Values are indicated as $\pm \mathrm{SE}$, $\mathrm{n}=3$. 


\section{Phytoremediation trials at polluted site of Carpiano}

A large set of field crops was screened for tolerance to $\mathrm{Cd}$ and $\mathrm{Cr}$ in the polluted soil of Carpiano at an early stage of pot cultivation (45 days). Despite the high contamination (Cd: 89, Cr: $452 \mathrm{mg} \mathrm{kg}^{-1}$ ), maximum shoot content was $27 \mathrm{mg} \mathrm{Cd} \mathrm{kg}^{-1}$ and $60 \mathrm{mg} \mathrm{Cr} \mathrm{kg}^{-1}$ in white and red clover, sugarbeet and sunflower (Figure 2). High metal accumulation usually corresponded to substantial biomass reduction, a common effect in cases of metal pollution.

Since several Brassicaceae species are reported to be hyperaccumulators (Terry and Bañuelos, 2000) and many others tolerate metal pollution, the test on garden cress (Lepidium sativum L.), rapeseed, fodder radish and Indian mustard provided useful information on their morphological response to contamination. The species were cultivated in 0.45-m deep rhizoboxes filled with the polluted soil of Carpiano, covered with a 7-cm thick layer of unpolluted soil, in comparison with an unpolluted silty-loam soil from the University of Padova Experimental Farm. Pollution caused generalised impaired shoot and root growth, reductions ranging from $36 \%$ to $80 \%$ for shoot biomass and from $25 \%$ to $54 \%$ for root length, in Indian mustard and rapeseed, respectively. The only exception was fodder radish in which, surprisingly, increased growth of both plant compartments $(+154$ and $+32 \%)$ was observed (Vamerali et al., 2004a). Roots were less sensitive to pollution, as shown by the unchanged root distribution along the soil profile $(\sim 60 \%$ of length colonising the polluted layer). Owing to its high productivity, fodder radish achieved the highest phytoextraction and garden cress the lowest, mainly represented by $\mathrm{Zn}$ (>96\%).

The anomalous behaviour of fodder radish suggested extending the investigation to a wide range of genotypes until plant maturity. At flowering, the six varieties cultivated in large pots with a top 5-cm unpolluted layer did show the same response observed in the previous experiment, i.e. higher shoot and root productivity than controls (Mosca et al., 2004). Fodder radish considerably promoted fine root production (up to $+182 \%$ in cv. Diablo), an effect probably responsible for poor metal translocation (Table 3); relatively high translocation factors were found for $\mathrm{Zn}, \mathrm{Cd}, \mathrm{Mn}$ and $\mathrm{Co}$. Above-ground, the main accumulated metals were $\mathrm{Zn}$ and $\mathrm{Mn}$, their concentrations exceeding 400 and $30 \mathrm{mg}$ $\mathrm{kg}^{-1}$, respectively (Table 3). The high intraspecific variability of all pollutants, particularly $\mathrm{Pb}$, confirms the possibility of selecting highly efficient genotypes.

The importance of roots in phytoremediation was observed at various levels. The biomass fraction (fine roots) exploring the polluted layer in the above experiment was positively correlated with the overall metal concentrations in shoots $\left(\mathrm{R}^{2}=0.65\right)$ (Vamerali et al., 2004b). Similar results were obtained in pots with pyrite cinders by overlaying a top unpolluted soil layer in fodder radish, sunflower and alfa-alfa (Medicago sativa L.) (data not shown). In this experiment, root length was also positively correlated with shoot metal concentrations $\left(\mathrm{R}^{2}=0.54\right)$, highlighting the importance of promoting root growth through agronomic management.
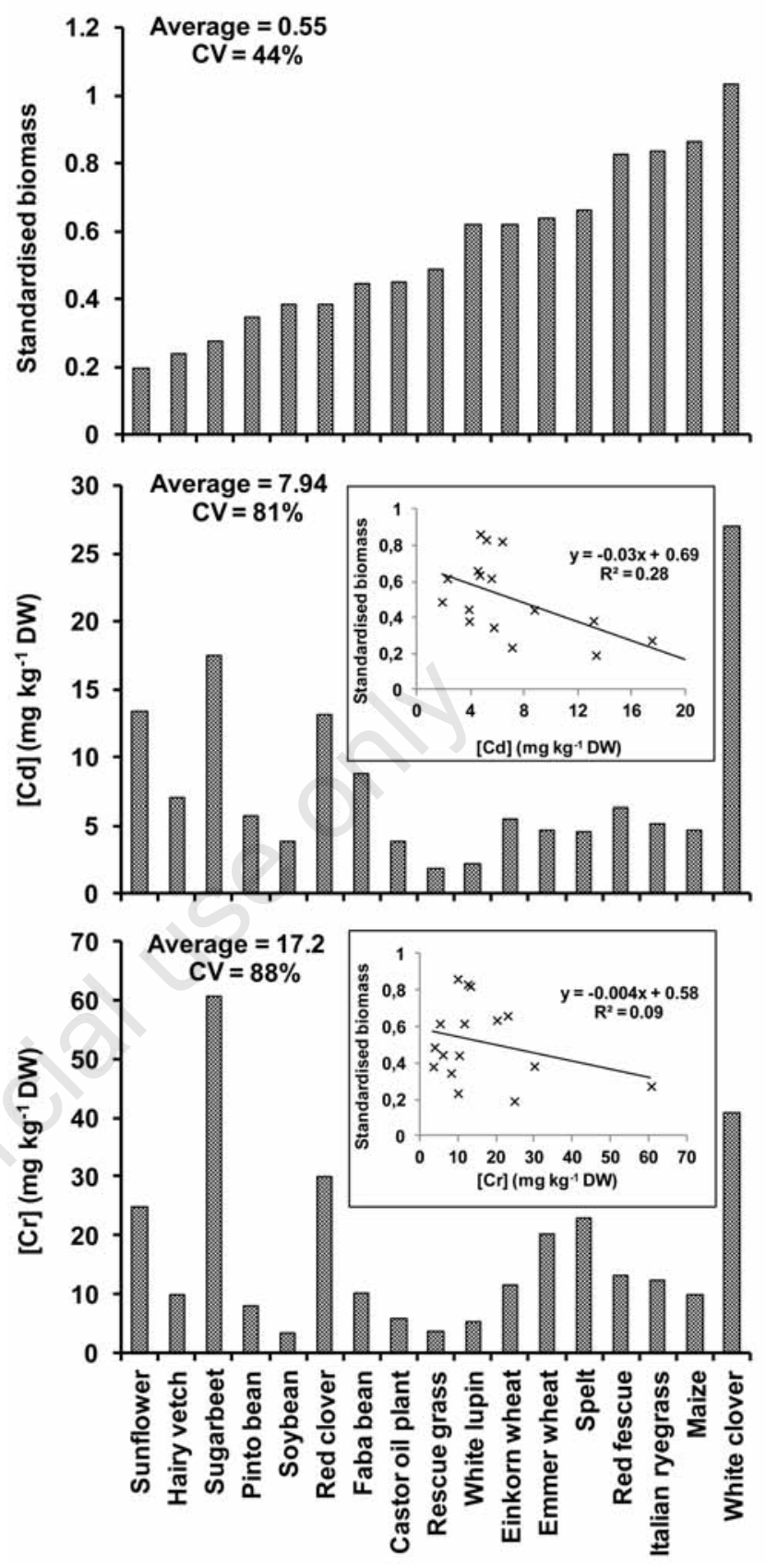

Figure 2. Pot experiment with polluted soil of Carpiano: shoot biomass (standardised on controls) (top), and shoot cadmium (middle) and chromium (bottom) concentrations in 45-day-old plants. Correlations between biomass and metal concentrations in boxes (white clover excluded in correlation).

Table 3. Pot experiment with polluted soil of Carpiano: shoot and root metal concentrations as average of 6 fodder radish genotypes and coefficient of variation.

\begin{tabular}{lcccccccccc} 
& & $\begin{array}{c}\mathrm{Cd} \\
\left(\mathrm{mg} \mathrm{kg}^{-1}\right)\end{array}$ & $\begin{array}{c}\mathrm{Co} \\
\left(\mathrm{mg} \mathrm{kg}^{-1}\right)\end{array}$ & $\begin{array}{c}\mathrm{Cr} \\
\left(\mathrm{mg} \mathrm{kg}^{-1}\right)\end{array}$ & $\begin{array}{c}\mathrm{Cu} \\
\left(\mathrm{mg} \mathrm{kg}^{-1}\right)\end{array}$ & $\begin{array}{c}\mathrm{Mn} \\
\left(\mathrm{mg} \mathrm{kg}^{-1}\right)\end{array}$ & $\begin{array}{c}\mathrm{Ni} \\
\left(\mathrm{mg} \mathrm{kg}^{-1}\right)\end{array}$ & $\begin{array}{c}\mathrm{Pb} \\
\left(\mathrm{mg} \mathrm{kg}^{-1}\right)\end{array}$ & $\begin{array}{c}\mathrm{Zn} \\
\left(\mathrm{mg} \mathrm{kg}^{-1}\right)\end{array}$ \\
\multirow{2}{*}{ Shoot } & Mean & 2.05 & 0.38 & 1.23 & 7.48 & 33.5 & 2.54 & 1.38 & 409 \\
& CV (\%) & 41 & 20 & 20 & 37 & 28 & 25 & 123 & 36 \\
\multirow{2}{*}{ Roots } & Mean & 2.34 & 0.70 & 7.59 & 34.9 & 45.0 & 4.35 & 4.20 & 475 \\
& CV (\%) & 34 & 17 & 32 & 16 & 21 & 20 & 52 & 37 \\
\hline TF & & 0.88 & 0.72 & 0.23 & 0.23 & 0.83 & 0.67 & 0.42 & 0.92 \\
\hline
\end{tabular}

$\mathrm{CV}$, coefficient of variation; TF: translocation factor (shoot-to-root metal concentration ratio). 
Cultivation of oilseed rape, sunflower, maize and fodder radish in large plots at the field site of Carpiano allowed us to estimate a realistic phytoremediation balance. The high soil fertility probably attenuated phytotoxicity, as all the crops grew regularly without evident detrimental effects. On a hectare basis, a maximum of $8.1 \mathrm{~kg}$ of various elements was harvested by rapeseed, followed by sunflower $(3.8 \mathrm{~kg}$ ), maize $(2.1 \mathrm{~kg})$ and fodder radish $(1.3 \mathrm{~kg})$, mainly due to $\mathrm{Zn}, \mathrm{Mn}$ and $\mathrm{Cu}$ (Figure 3). These promising results were in large part due to good above-ground productivity, but phytomanangement of the site was carried out for one year only, and the dynamics of metal bioavailability and whether phytoremediation efficiency remains acceptable across cultivation cycles should be further investigated.

\section{Agronomic practices in pyrite waste}

Worldwide, a large number of sites are pluri-contaminated, especially in cases of industrial wastes. After the encouraging experiments in the agricultural soil of Carpiano, we achieved further insights on phytomanagement through experiments on pyrite waste at Torviscosa. The poor spontaneous vegetation cover of the site predicted difficulties in crop establishment and growth. In this framework, we tested some agronomic practices to improve plant productivity and metal accumulation.

In preliminary pot trials, mixing cinders with unpolluted topsoil allowed various crop species to grow regularly at two pyrite rates, i.e. $50 \%$ and $66 \% \mathrm{v} / \mathrm{v}$ (Fellet et al., 2007). Of soybean, sorghum, sunflower and maize, the last even provided the greatest biomass at the highest contamination rate. The lower waste rate was effective in enhancing root metal concentrations, but did not lead to significant benefits as regards metal translocation and removals.

Given the particular soil stratigraphy of the Torviscosa site (unpolluted capping layer), we compared two soil managements, ploughing $v s$. ripping, both at a depth of $0.3 \mathrm{~m}$, in order either to mix layers or to maintain stratigraphy almost unchanged. In the sowing bed (top 0.15 $\mathrm{m}$ layer), pollution was roughly halved by ploughing and, despite some upward cinder movement, ripping led to lower contamination than ploughing (total and DTPA-extractable: -30\%) (Table 2). Contamination and extreme soil conditions caused markedly impaired growth in Italian ryegrass (Lolium multiflorum L.), alfa-alfa, sunflower and fodder radish, under both tillages (controls set in the silty-loam soil of the University of Padova farm). Tillage choice was not critical for phytoextraction, although ripping enhanced mainly above-ground productivity (up to $+79 \%$ in sunflower) and ploughing shoot metal concentrations (up to $+33 \%$ in Italian ryegrass). Fodder radish deserved particular attention, as its greater biomass allowed the best removal, 0.33 $\mathrm{kg}$ of various elements on a hectare basis (Table 4), perhaps due to the poor sensitivity of its roots to pollution. However, removals were generally scarce, much lower than those detected at the Carpiano site, but again $\mathrm{Zn} \mathrm{(62 \% )} \mathrm{and} \mathrm{Cu}(18 \%)$ were the main contaminants harvested (Vamerali et al., 2011b). In all species, poor fine root proliferation was a constraining factor, a result which was also observed at the same site in woody species (Vamerali et al., 2009). Roots were generally confined to the shallow $0.3-\mathrm{m}$ deep layer, although growth improvement was obtained under ripping (root density: 5.7 vs $4.9 \mathrm{~cm} \mathrm{~cm}^{-3}$ of ploughing).

In this on-site trial we enhanced soil fertility by supplying $100 \mathrm{~kg} \mathrm{ha}^{-1}$ of each macronutrient $\left(\mathrm{N}, \mathrm{P}_{2} \mathrm{O}_{5}\right.$ and $\left.\mathrm{K}_{2} \mathrm{O}\right)$, an agronomic aspect to be con-
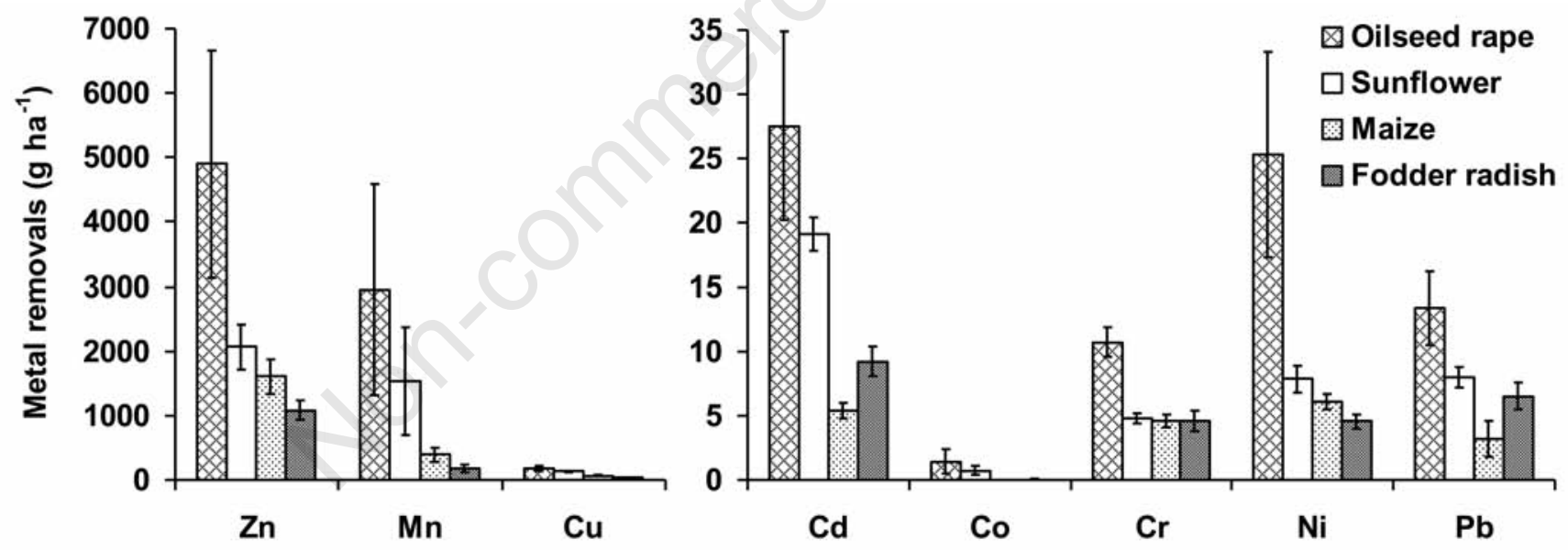

Figure 3. Field experiment at Carpiano: metal removals by canopy on hectare basis $(\mathrm{SE} \pm \mathrm{n}=3)$ with crop species. Note different scale between graphs.

Table 4. Soil tillage trial (ploughing $v$ s ripping) at Torviscosa: metal removals (g on hectare basis) by canopy of species grown in pyrite waste.

\begin{tabular}{lcccc} 
& Sunflower & Italian ryegrass & Alfa-alfa & Fodder radish \\
$\mathrm{As}$ & $0.16 \pm 0.16^{\mathrm{b}}$ & $4.23 \pm 1.54^{\mathrm{b}}$ & $3.35 \pm 0.80^{\mathrm{b}}$ & $10.2 \pm 2.4^{\mathrm{a}}$ \\
$\mathrm{Cu}$ & $25.6 \pm 10.7^{\mathrm{b}}$ & $31.0 \pm 9.5^{\mathrm{b}}$ & $16.1 \pm 2.9^{\mathrm{b}}$ & $73.0 \pm 7.1^{\mathrm{a}}$ \\
\hline $\mathrm{Mn}$ & $22.2 \pm 10.0^{\mathrm{ab}}$ & $15.0 \pm 1.5^{\mathrm{ab}}$ & $9.58 \pm 1.72^{\mathrm{b}}$ & $29.2 \pm 5.9^{\mathrm{a}}$ \\
$\mathrm{Zn}$ & $106 \pm 37^{\mathrm{b}}$ & $141 \pm 43^{\mathrm{ab}}$ & $49.5 \pm 5.3^{\mathrm{b}}$ & $206 \pm 27^{\mathrm{a}}$ \\
\hline Overall removal & $166 \pm 55^{\mathrm{b}}$ & $211 \pm 54^{\mathrm{ab}}$ & $91.4 \pm 8.3^{\mathrm{b}}$ & $331 \pm 38^{\mathrm{a}}$ \\
\hline
\end{tabular}

As, arsenic; $\mathrm{Cu}$, copper; $\mathrm{Mn}$, manganese; $\mathrm{Zn}$, zinc. Values are indicated as species' main effect $\pm \mathrm{SE} ; \mathrm{n}=6$ ). Overall removal: $\mathrm{As}+\mathrm{Cu}+\mathrm{Mn}+\mathrm{Zn}+\mathrm{Cd}+\mathrm{Co}+\mathrm{Pb}+\mathrm{Ni}+\mathrm{Cr}$. a,b Differences among species within same pollutant (Newman-Keuls test, $\mathrm{P} \leq 0.05$ ) 
sidered carefully when dealing with unfertile wastes. Indeed, at the same site, sorghum and sunflower provided very small above-ground biomass in the absence of fertilisation, 1.54 and $0.37 \mathrm{t} \mathrm{ha}^{-1} \mathrm{DW}$, respectively (Marchiol et al., 2007), whereas 10-to-20-fold productivity increases were achieved with either abundant mineral ( $\mathrm{N}-\mathrm{P}_{2} \mathrm{O}_{5}-\mathrm{K}_{2} \mathrm{O}: 150-30-60 \mathrm{~kg} \mathrm{ha}^{-1}$ in sorghum and 150-30-290 $\mathrm{kg} \mathrm{ha}^{-1}$ in sunflower) or organic $\left(90 \mathrm{t} \mathrm{ha}^{-1}\right.$ of mature cow manure) fertilisation (Figure 4) (Marchiol et al., 2007). There was a species-specific response, as productivity was higher under mineral fertilisation in sorghum and the opposite occurred in sunflower, with a tendency towards higher metal concentrations associated with lower biomass. In this fertilisation trial, the phytoremediation potential increased with respect to the soil tillage experiment, as $\mathrm{Zn}$ removal alone by sorghum reached $2 \mathrm{~kg}$ on a hectare basis, matching results by Madejón et al. (2003) in pyrite waste in Spain. For phytoremediation of poor fertile wastes, sufficient supply of nutrients is important, but attention should also be paid to the chemical form of fertilisers. For instance, in the Carpiano soil, significant metal concentration increases in shoot tissues were found in plants fed with ammonium instead of nitrate, with further improvements with the contemporaneous application of nitrification inhibitors (Zaccheo et al., 2006).

\section{Organic amendments}

In our fertilisation trial, removals of some metals were enhanced by manure, a fact suggesting that organic matter plays an active role in soil porewater metal mobility, as variously reported in the literature (e.g. Lagier et al., 2000). In this regard, an attempt to make pyrite cinders more hospitable and improve phytoremediation was made by adding humic acids to the waste and directly to fodder radish. The highest amendant dose of $1 \mathrm{~g} \mathrm{~kg}^{-1}$ reduced root length, shoot biomass and, unfortunately, metal removals, although we observed increased concentrations of metals in shoots (various elements: $+44 \%$ ) (Bandiera et al., 2009). This response was probably caused by increases in metal influx (Halim et al., 2003) and the chelating ability of humic acids. Indeed, these compounds improved the translocation of all metals, except $\mathrm{Pb}$, which is commonly retained at root level (Saygideger and Dogan, 2005). As a consequence of increased root growth $(+46 \%$ in length) and uptake, a result probably due to the auxin-like effect of humic substances (Pizzeghello et al., 2002; Hager et al., 2003), enhanced plant metal removals were achieved only at the small dose of humic acids, $0.1 \mathrm{~g} \mathrm{~kg}^{-1}$, mixed with the waste. This seems an economically interesting result for practical applications on a large scale, due to the high costs of humic acid-based commercial products.

\section{Exogenous application of phytohormones}

The possible influence of auxins in phytoremediation was tested in pyrite waste in a pot-based trial. Unfortunately, with the exception of foliar spraying alone, IBA reduced shoot and root biomass $(-60 \%$ on average) when applied to the waste, probably due to unsuitable dosages (Vamerali et al., 2011a). Metal removals were greatly worsened by IBA, in spite of improvements in concentrations due to the chelating effect of this phytohormone, which is expected to remain longer in the low microbial activity conditions of our pyrite.

\section{Chelate-assisted phytoremediation}

Improved metal harvest has been widely achieved in the past through chelator-assisted phytoremediation, a practice often dismissed because of the potential risks of high leaching. However, the most frequently used ethylene diamine tetraacetic acid (EDTA) can now be replaced by new, low-persistent, high-degradable chelators, like nitrilotriacetic acid (NTA) and ethylene diamine disuccinic acid (EDDS) (Quartacci et al., 2007). In pyrite waste cultivated with Ethiopian mustard and fodder radish, although only at pot level, we obtained important indications for the use of the [S,S]-EDDS stereoisomer in the open. At our tested doses, the chelator did successfully improve $\mathrm{Cu}, \mathrm{Co}$, $\mathrm{Zn}$ and $\mathrm{Pb}$ concentrations in the above-ground biomass of both species, together with $\mathrm{Cu}$ translocation, but reduced plant biomass especially with repeated applications and in radish (Bandiera et al., 2010b). This may have a direct effect on leaching, as a lower leaf area caused a drop in transpiration and significant losses of $\mathrm{Cu}$, the metal with the greatest stability constant with EDDS (Tandy et al., 2004).

Although these results on the use of EDDS and its management require confirmation in open fields, until now better metal phytoextraction together with minimal metal leaching seems achievable with moderate, close-to-harvest chelator applications.

\section{Inorganic amendments}

Since phytoremediation is a long-term solution, the possibility of immobilising metals may reduce phytotoxicity and downward metal movements. Soil amendment may represent a way of achieving this objective, and some interesting results have recently been obtained with inorganics (Hartley and Dickinson, 2009). In our trial, we expected that cement acted by capping pollutants, lime by raising $\mathrm{pH}$, and iron sulphate by immobilising As (Hartley et al., 2004). Lime and cement at small rates (1\%) did reduce the mobility of $\mathrm{Pb}, \mathrm{Cu}$ and $\mathrm{Zn}$, but not of $\mathrm{Cd}$ (Figure 5) (Bandiera et al., 2010a). Due to their relatively small active rate, we conclude that cement and lime can be applied cheaply on a large scale, with some attention to lime, which raises $\mathrm{pH}$ and As mobilisation (Moreno-Jiménez et al., 2012).

Recent studies suggest that the application of biochar may improve highly degraded land (Lehnmann and Rondon, 2006; Mench et al., 2007; Kumpiene et al., 2008). In our mine tailings, substrate $\mathrm{pH}$, cation

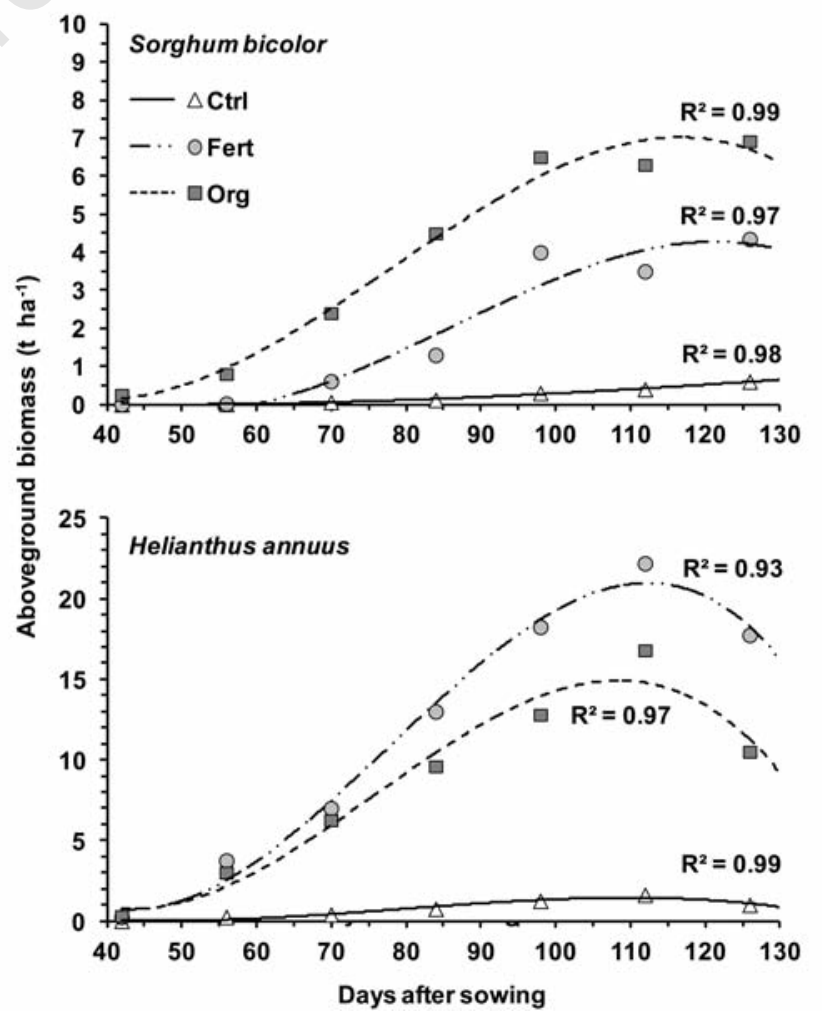

Figure 4. Fertilisation trial at Torviscosa: dynamics over time of above-ground biomass $(n=3)$ in crops grown in untreated (Ctrl), mineral-fertilised (Fert) and organic-amended (Org) pyrite cinders. Note different scale between graphs. 

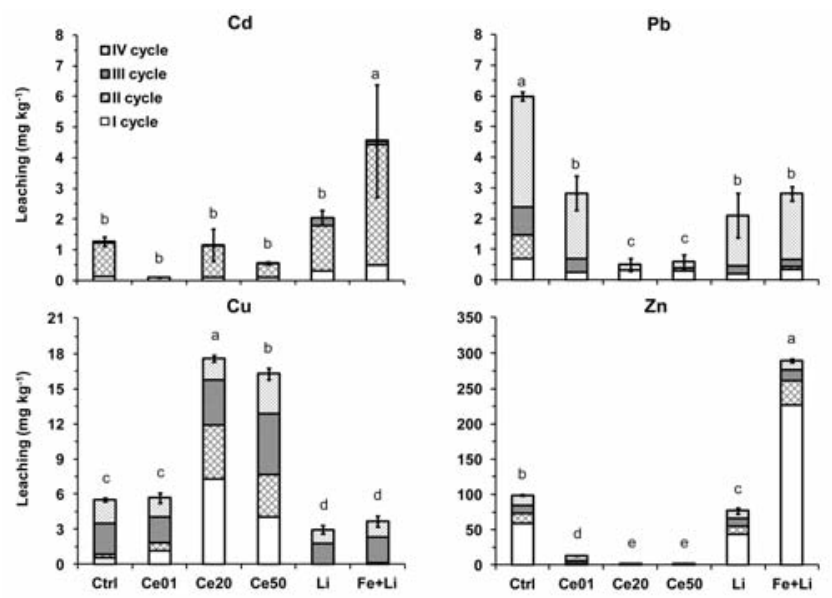

Figure 5. Woolston New Cut Canal sediments: metal leaching $(n=3 ; \pm S E)$ during 4 cycles of wetting-drying extraction after amendment. Untreated controls (Ctrl); cement 1\% w/w (Ce01); cement 20\% w/w (Ce20); cement 50\% w/w (Ce50); lime 1\% w/w (Li); iron sulphate $0.5 \%+$ lime $0.5 \%$ w/w $(\mathrm{Fe}+\mathrm{Li})$. a-e: differences among amendments for total leaching (Newman-Keuls test, $\mathbf{P} \leq 0.05)$.

exchange and water-holding capacities were increased by biochar, according to amendant rate. Biochar retained considerable fractions of metals, reducing bioavailability and possibly favouring the establishment of a green cover in phytostabilisation (Fellet et al., 2011). In the agricultural soil of Carpiano, lowered $\mathrm{Cu}$ and $\mathrm{Zn}$ extractability was achieved by Contin et al. (2008) after repeated cycles of soil saturation with $0.1 \mathrm{M} \mathrm{FeSO}_{4}$, air drying and $\mathrm{pH}$ neutralisation with $\mathrm{Ca}(\mathrm{OH})_{2}$, but with increased $\mathrm{Ni}$ and $\mathrm{Mn}$ mobility.

\section{Conclusions}

Phytoextraction alone is rarely an efficient process for remediation of metal-contaminated sites, as the time required for removing merely the most labile fraction of pollutants (bioavailable contaminant stripping) is generally very long. Zinc, $\mathrm{Mn}$ and $\mathrm{Cu}$ are the only metals which field crops can take up and translocate above-ground at relatively high rates, and inter- and intra-specific variability is worth exploring for suitable species and genotype selection. In several trials, we highlighted the key role of plant roots in phytoextraction and phytostabilisation, since more roots are expected to take up a greater amount of pollutants, and they represent a significant metal sink. In planta metal stabilisation may be a reliable way of reducing leaching risks, primarily through large coarse- and tap-root systems, and investigation of the dynamics of long-term retention is in progress at the University of Padova. Currently, containment of metal leaching can be ensured by a well-developed leaf apparatus to sustain high rates of water transpiration and by soil amendment with suitable inorganics and biochar.

Many substances tested over our long-term research program, such as auxins, humic acids and chelators, can increase concentrations of metals in plant tissues, but frequently reduce biomass yield. For efficient phytoremediation with field crops, it seems preferable to enhance productivity rather than metal concentration. For this goal, minimised wind erosion and soil metal movements, and easier mechanical harvesting seem achievable by substrate dilution and capping with clean soil, together with adequate fertilisation and amendment.

\section{References}

Bandiera M, Dickinson NM, Hartley W, Vamerali T, 2010a. Remediation of canal sediment exposed to continued wetting and drying: effect on metal mobility by inorganic amendment addition. Page 135 in Proc. 7th Int. Phytotechnol. Conf., Parma, Italy.

Bandiera M, Mosca G, Vamerali T, 2009. Humic acids affect root characteristics of fodder radish (Raphanus sativus L. var. oleiformis Pers.) in metal-polluted wastes. Desalination 247:79-92.

Bandiera M, Mosca G, Vamerali T, 2010b. Phytotoxicity and metal leaching in EDDS-assisted phytoextraction from pyrite wastes with Ethiopian mustard and fodder radish. Plant Biosyst. 144:490-8.

Bona S., Ganis A., Vamerali T., Mosca G., 2002a. Effects of cadmium and chromium on seed germination and early growth in Brassicaceae species. pp 797-798 in Proc. 7th Congr. Eur. Soc. Agron, Córdoba, Spain.

Bona S., Ganis A., Vamerali T., Mosca G., 2002b. Phytoextraction of heavy metals with Brassicaceae species in contaminated soil. pp 799-800 in Proc. 7th Congr. Eur. Soc. Agron, Córdoba, Spain.

Coletto L, Vamerali T, Mosca G, 2006. Characterization of a site polluted by pyrite cinders and heavy metals for setting up profitable phytoremediation strategies. pp 629-630 in Proc. 9th Congr. Eur. Soc. Agron., Part II, Warsaw, Poland.

Contin M, Mondini C, Leita L, Zaccheo P, Crippa L, De Nobili M, 2008. Immobilisation of soil toxic metals by repeated additions of Fe(II) sulphate solution. Geoderma 147:133-140.

Ernst WHO, 2005. Phytoextraction of mine wastes - options and impossibilities. Chem Erde-Geochem. 65:29-42.

European Environment Agency, 2011. Progress in management of contaminated sites (CSI 015) - assessment published Aug 2007. Available from: http://www.eea.europa.eu/data-and-maps/indicators/progress-in-management-of-contaminated-sites/progress-inmanagement-of-contaminated-1.

Fellet G, Marchiol L, Delle Vedove G, Peressotti A, 2011. Application of biochar on mine tailings: effects and perspectives for land reclamation. Chemosphere 83:1262-1267.

Fellet G, Marchiol L, Perosa D, Zerbi G, 2007. The application of phytoremediation technology in a soil contaminated by pyrite cinders. Ecol. Eng. 31:207-214.

Hager A, 2003. Role of the plasma membrane H+-ATPase in auxininduced elongation growth: historical and new aspects. J. Plant Res. 116:483-505.

Halim M, Conte P, Piccolo A, 2003. Potential availability of heavy metals to phytoextraction from contaminated soils induced by exogenous humic substances. Chemosphere 52:265-275.

Hartley W, Dickinson NM, 2009. Exposure of an anoxic and contaminated canal sediment: mobility of metal(loid)s. Environ. Pollut. 158:649-657.

Hartley W, Edwards R, Lepp NW, 2004. Arsenic and heavy metal mobility in iron oxide-amended contaminated soils as evaluated by shortand long-term leaching tests. Environ. Pollut. 131:495-504.

Kumpiene J, Lagerkvist A, Maurice C, 2008. Stabilization of As, $\mathrm{Cr}, \mathrm{Cu}$, $\mathrm{Pb}$ and $\mathrm{Zn}$ in soil using amendments - a review. Waste Manage. 28:215-225.

Lagier T., Feuillade G., Matejka G., 2000. Interactions between copper and organic macromolecules: determination of conditional complexation constants. Agronomie 20:537-546.

Lasat MM, 2002. Phytoremediation of toxic metals: a review of biological mechanisms. J. Environ. Qual. 31:109-20.

Lehmann J, Rondon M, 2006. Biochar soil management on highly weathered soils in the humid tropics. In: A.S. Ball, E. Fernandes, H. Herren, 0. Husson, M. Laing, C. Palm, J. Pretty, P. Sanchez, N. Sanginga and J. Thies (eds.) Biological approaches to sustainable 
soil systems. CRC Press, Boca Raton, FL, pp 517-530.

Madejón P, Murillo JM, Marañón T, Cabrera F, Soriano MA, 2003. Trace element and nutrient accumulation in sunflower plants two years after the Anzalcóllar mine spill. Sci. Total Environ. 307:239-257.

Marchiol L, Assolari S, Fellet G, Zerbi G, 2006. Germination and seedling growth of Indian mustard exposed to cadmium and chromium. Int. J. Agron. 1:45-9.

Marchiol L, Fellet G, Perosa D, Zerbi G, 2007. Removal of trace metals by Sorghum bicolor and Helianthus annuus in a site polluted by industrial wastes: a field experience. Plant Physiol. Biochem. 45:379-387.

Mench M, Vangronsveld J, Lepp NW, Ruttens A, Bleeker P, Geebelen W, 2007. Use of soil amendments to attenuate trace element exposure: sustainability, side effects, and failures. In: R.E. Hamon, M. McLaughlin and E. Lombi (eds.) Natural attenuation of trace element availability in soils. SETAC Press, Pensacola, FL, USA, pp 197228.

Moreno-Jiménez E, Esteban E, Peñalosa JM, 2012. The fate of arsenic in soil-plant systems. Rev. Environ. Contam. Toxicol. 215:1-37.

Mosca G, Vamerali T, Ganis A, Coletto L, Bona S, 2004. Miglioramento dell'efficienza agronomica della fitodecontaminazione di metalli pesanti. In: G. Zerbi and L. Marchiol (eds.) Fitoestrazione di metalli pesanti. Contenimento del rischio ambientale e relazioni suolomicrorganismi-pianta. Forum Ed., Udine, Italy, pp 105-135.

Pizzeghello D, Nicolini G, Nardi S, 2002. Hormone-like activities of humic substances in different forest ecosystems. New Phytol. 155:393-402.

Quartacci MF, Irtelli B, Baker AJM, Navari-Izzo F, 2007. The use of NTA and EDDS for enhanced phytoextraction of metals from a multiply contaminated soil by Brassica carinata. Chemosphere 68:19201928.

Raskin I, Kumar PBAN, Dushenkov S, Salt D, 1994. Bioconcentration of heavy metals by plants. Curr. Opin. Biotechnol. 5:285-290.
Saygideger S, Dogan M, 2005. Influence of pH on lead uptake, chlorophyll and nitrogen content of Nasturtium officinale R. Br. and Mentha aquatica L. J. Environ. Biol. 26:753-759.

Tandy S, Bossart K, Mueller R, Ritschel J, Hauser L, Schulin R, 2004. Extraction of heavy metals from soils using biodegradable chelating agents. Environ. Sci. Technol. 38:937-944.

Terry N, Bañuelos GS, 2000. Phytoremediation of Contaminated Soil and Water. CRC Press, Lewis Publ, Boca Raton, FL.

USEPA, 1994. Microwave-assisted acid digestion of sediments, sludges, soils and oils. Method 305. Washington, DC, USA.

Vamerali T, Bandiera M, Coletto L, Zanetti F, Dickinson NM, Mosca G, 2009. Phytoremediation trials on metal- and arsenic-contaminated pyrite wastes (Torviscosa, Italy). Environ. Pollut. 157:887-894.

Vamerali T, Bandiera M, Hartley W, Mosca G, 2011a. Assisted phytoremediation of mixed metal(loid)-polluted pyrite waste: effects of foliar and substrate IBA application on fodder radish. Chemosphere 84:213-219.

Vamerali T, Bandiera M, Mosca G, 2010. Field crops for phytoremediation of metal-contaminated land. A review. Environ. Chem. Lett. $8: 1-17$.

Vamerali T, Bandiera M, Mosca G, 2011b. In situ phytoremediation of metal-polluted pyrite waste with field crops under differing soil managements. Chemosphere 83:1241-1248.

Vamerali T, Ganis A, Bona S, Mosca G, 2004a. Effects of heavy metals on root establishment of Brassicaceae species in highly contaminated soil. pp 475-476 in Proc. 8th ESA Conf., Copenhagen, Denmark.

Vamerali T, Ganis A, Mosca G, 2004b. Intraspecific variability of radish (Raphanus sativus) grown on heavy-metal polluted soil. pp 471-472 in Proc. 8th ESA Conf., Copenhagen, Denmark.

Zaccheo P, Crippa L, Di Muzio Pasta V, 2006. Ammonium nutrition as a strategy for cadmium mobilization in the rhizosphere of sunflower. Plant Soil 283:43-56. 